\title{
Evaluating the Effectiveness of Agricultural Adaptation to Climate Change in Pre-Industrial Society
}

\begin{abstract}
The effectiveness of agricultural adaptation determines the vulnerability of this sector to climate change, particularly during the pre-industrial era. However, this effectiveness has rarely been quantitatively evaluated, specifically at a large spatial and long-term scale. The present study covers this case of pre-industrial society in AD 1500-1800. Given the absence of technological innovations in this time frame, agricultural production was chiefly augmented by cultivating more land (land input) and increasing labor input per land unit (labor input). Accordingly, these two methods are quantitatively examined. Statistical results show that within the study scale, land input is a more effective approach of mitigating climatic impact than labor input. Nonetheless, these observations collectively improve Boserup's theory from the perspective of a large spatial and long-term scale.
\end{abstract}

\section{KEY WORDS}

Adaptation; Climate change; Labor input; Land input; Pre-industrial society 


\section{Introduction}

Climate change is a major global concern because it can trigger socio-economic disasters (IPCC 2007, Zhang, Lee, Cong Wang, et al. 2011). The vulnerability of human societies to climate change is determined by the effectiveness of their adaptation and coping mechanisms with climatic impact (IPCC 2007, Watson, Zinyowera, and Moss 1998, Patz et al. 2005). Among all social sectors, the agricultural sector is the most sensitive to climate change (Schmidhuber and Tubiello 2007). This assertion was particularly true in the pre-industrial era, which has a low technological level (Galloway 1986). Accordingly, the economic development of agrarian societies in the past was primarily determined by climate change in the long term (Pei et al. 2013, Pei et al. 2014).

The above conditions suggest that the effectiveness of agricultural adaptation to climate change in the past must be reexamined. Existing studies on this research topic fail to explore the effectiveness of each method for reducing the negative effects of climate change because the number of quantitative evidence for concise assessment is insufficient (Tol, Fankhauser, and Smith 1998). The different adaptation mechanisms to climate change can be viewed and interpreted with different scales (Adger 2003). Nonetheless, existing research only focuses on past adaptation as mere case studies in a relatively limited scale (Ford, Smit, and Wandel 2006, Purkey et al. 2008, Kirshen, Ruth, and Anderson 2008).

Complex nature-society interactions should be disentangled at large spatial and long-term scales (MacDonald and Iain 1998, Miller 1990, Butlin 1993). Before the year AD 1800, China and Europe were at the similar level of social development. Therefore, the two regions are often examined together when investigating the 
societal impact of climate change in the pre-industrial era (Little 2008). In recent years, the agrarian economy in pre-industrial Europe has received considerable attention (Pei et al. 2013, Pei et al. 2014, Zhang, Lee, Wang, et al. 2011). Also, the findings on pre-industrial Europe have been employed to comprehend the economic conditions in historical China (Fei and Zhou 2015, Lee 2014). In line with the above rubric, in the present study, we systematically evaluated the effectiveness of agricultural adaptation to climate change in pre-industrial Europe, with the objective to mirror the condition in historical China.

The continental integration of the grain market in Europe began in the early modern period (Chilosi et al. 2013, Özmucur and Pamuk 2007). Therefore, the present study adopts the continental scale and takes Europe (Figure 1) as the study area because of its long history of crop cultivation (Hartmann et al. 1981). However, a major methodological difficulty remains within historical society. Early history is less certain and more fragmented than modern times because documentary data during the former are minimal and insufficient. Nevertheless, focusing on a particular socio-economic formation is necessary when disentangling any complex human phenomenon. Thus, this study focuses only on AD 1500-1800, a period that is associated with well-established datasets on paleoclimate change and yield ratio. This period also falls within the Little Ice Age (Osborn and Briffa 2006), during which agricultural production was regularly subjected to severe drawbacks (Ewert, Roehl, and Uhrmache 2007). Moreover, AD 1500-1800 encompasses the general crisis of the 17th century (AD 1560-1660) (Fischer 1996).

In the pre-industrial era, insufficient market integration and strict regulation repressed the realization of free trade (Karl 1999). Furthermore, both international and interregional collaborations were hampered by poor transportation (Pounds 1979, 
Vries 1976, Wood 1998). Although global connections have been suggested since AD 1500 (Wallerstein 1974, 1980), trade was mainly confined to commercial products until the early 20th century (Ogborn 2000). At this time, agricultural adaptation to climate change only materialized by boosting production within the context of low and slowly advancing technology (Clark 2007). Consequently, because this era saw limited technological innovations, agricultural production was augmented by cultivating more land (land input) (Romano 1997, Campbell 2000) and increasing labor input per land unit (labor input) (Campbell 2000, van Bath 1966). Land input and labor input are the two most feasible approaches for augmenting agricultural production in the pre-industrial era.

In addition to the above-mentioned adaptive methods, other unique approaches may also exist in each country across the Eurasian continent. Such differences at the national scale can be neutralized if the subject at hand is examined at the continental scale (Zhang et al. 2007). Accordingly, we evaluate the land and labor inputs as the essence of agricultural production on the basis of current literature to fill the research gap in quantitative studies on agricultural adaptation to climate change in pre-industrial society. Little attention is given to individual incidents that temporarily distort agricultural production because this research covers 300 years at a continental scale. This broad-brush approach suits the scope of the study despite its limitations.

\section{Methodology and Data}

Datasets were obtained from previous studies on pre-industrial Europe(Zhang, Lee, Wang, et al. 2011), and the significance level was set as 0.05 (95\%).

\subsection{Temperature}


At the continental scale, temperature is proven to be a more important climatic factor for agrarian economies in pre-industrial society than precipitation (Pei et al. 2013, Pei et al. 2014). Temperature is also the appropriate indicator of climate change at a large spatial scale (Jones and Bradley 1992) and the most important factor in plant cultivation (Mathias 1990). Consequently, the current study adopted temperature to represent climatic condition. The temperature anomaly series was derived from two authoritative annual temperature reconstructions, namely, the annual temperature reconstruction for European land areas by Luterbacher et al. (2004) and the annual temperature dataset by Osborn and Briffa (2006), who combined the regional temperature series nested within Europe. We first normalized both of these reconstructions to homogenize the original variability because of their different proximities and methods used. These normalized series were then arithmetically averaged to generate the European temperature composite we adopted. Such a reconstruction was used to justify the causal relationships between climate change and social crisis (Zhang, Lee, Wang, et al. 2011).

\subsection{Yield Ratio}

We adopted yield ratio, a useful assessment of agricultural productivity (Brandon 1972). This measure not only reflects social production capacity but also determines both macro- and micro-economies in an agrarian society (van Bath 1966). Yield ratio was calculated as follows:

Yield ratio $=\frac{\text { Harvest amount }}{\text { Seed amount }}$.

Grain yield ratio was used to represent the yield ratio level of agriculture in the past. Grain refers to four small grain crops, namely, wheat, rye, barley, and oats. These 
crops are considered a necessity for daily human life and are consumed by $80 \%$ to 95\% of early modern population (Parker and Smith 1997). These grains have a few good substitutes, particularly in the pre-industrial period (van Bath 1963c, McConnell

and Bruce 2002, Spencer and Orley M. Amos 1993). The grain yield data used in this study were derived from the dataset of van Bath (1963b), which contains the grain yield ratio from 18 European countries. The grain yield ratios were arithmetically averaged to obtain the holistic conditions of the entirety of Europe.

\subsection{Agricultural Production Index}

Data on the total amount of agricultural production for Europe during the selected time span are unavailable. Alternatively, we compiled and calculated the agricultural production index (API) on the basis of a recent study (Zhang et al. 2007) that adopted two parameters, namely, population size and grain price. This data series was also applied to the study of climate change and social crisis in pre-industrial Europe (Zhang, Lee, Wang, et al. 2011).

\subsection{Population Size}

In this study, the population size of Europe was extracted from Atlas of World Population History by McEvedy and Jones (1978), a remarkably accurate work frequently used by scholars. Population data were collected at irregular time intervals. Thus, the common logarithm of the data points was calculated, linearly interpolated, and finally anti-logged back to produce an annual time series. This method avoids any distortions in the population growth rate caused by data interpolation.

A low-pass filter was obtained to smooth the data series for extracting long-term variations (Pollock 2000) to verify the effectiveness of long-term adaptation to 
climate change. Prior to conducting statistical analysis, we employed a 40-year low-pass Butterworth filter to smoothen all data series by following previous studies (Mann and Jones 2003, Pei et al. 2014).

\section{Effectiveness of Adaptive Methods}

In pre-industrial Europe, long-term cooling reduced the yield ratio and significantly dampened agricultural production. Figure 2 shows the temperature, yield ratio, API, and population size in the study period. The shadowed area in Figure 2 implies the lengthy and severe cooling period of AD 1560-1660, during which Europe endured a general crisis (cf. Section 1).

We cross-correlated temperature, yield ratio, and API to further verify the association between temperature and agricultural production. API shows an evident long-term trend (Figure 2C), but temperature and yield ratio do not. To guarantee the consistency among the data, API was linearly detrended prior to correlation analysis to extract the "real association" among the assorted variables (Turchin 2003). Table 1 illustrates that the variables are significantly and positively correlated at the significance level of 0.05 . The significant correlation results imply that temperature can affect the harvest amount by disturbing the yield ratio. Statistical analysis results quantitatively prove the dependence of agricultural production on temperature. In the following sections, the effectiveness of adaptation in agricultural activities was examined.

\subsection{Enlarging Cultivated Land Area (Land Input)}

At present, cropland and pasture account for $40 \%$ of the Earth's land surface (Foley et al. 2005). Agricultural land, which has been perceived as extremely important in 
agrarian societies, remains essential all over the world. Human history contains adequate records on the fight against famine under climate change (Hughes and Metcalfe 1972). Expanding cultivated land areas is considered a common method for relieving climatic impact (Orlove 2005), and managing land to cope with climate change is a key issue in the agricultural sector (D'Arrigo, Wilson, and Jacoby 2006). Adaptation methods based on land use and agricultural land cover can mediate climatic impacts at a large scale by increasing the resilience of ecological systems and decreasing catastrophic risks (Pyke and Andelman 2007). Although enlarging cultivated land areas in agricultural production cannot completely relieve climatic impacts (IPCC 2007), the existing studies and historical documents still generally consider land input as an important method of adaptation.

The total land area used for agricultural cultivation in pre-industrial Europe cannot be estimated because fallow land is often omitted in historical records (Thoen et al. 1999). The medieval stewards of local customary measures often precluded any accurate yield measurement per unit area (Moore-Colyer 1995). Hence, the effect of enlarging arable land area on agricultural production was inferred from the interrelationship between yield ratio and total amount of harvest. By performing a mathematical deduction on the formula of yield ratio, we indirectly scrutinized the effectiveness of land input. Therefore, Formula 1 can be rewritten as follows:

Harvest amount $=$ Seed amount $\times$ Yield ratio.

Accordingly, the harvest amount can be increased either by increasing the amount of sown seed by having a higher yield ratio or by both. Formula 2 can be expressed in a standard continuous growth equation. 


$$
\begin{aligned}
& \frac{d(\text { Harvest }}{\text { amount })}=\text { Seed } \text { amount } \\
& \frac{d(\text { Harvest amount })}{d(\text { Seed amount })}=\text { Yield ratio }
\end{aligned}
$$

Formula 3 implies that given a constant seed amount, the harvest amount can be changed depending on the variation of yield ratio and vice versa. During the cooling period, yield ratio decreases because of insufficient thermal energy. When yield ratio decreases, the harvest amount can be increased or maintained by increasing the amount of seeds sown. Nevertheless, the amount of seeds sown per land unit is subject to soil fertility and space constraints. Therefore, the amount of seeds sown in a given land unit cannot be increased endlessly. When more seeds are sown, more lands are needed for cultivation. In this event, in the absence of technological innovations, harvest amount can be increased by expanding the arable land areas (Romano 1997).

We further clarified the comparisons by presenting yield ratio and API together in Figure 3, which shows that the yield ratio was reduced in AD 1500-1610 and remained stagnant in AD 1610-1700. By contrast, API was steady in AD 1500-1640 and rapidly increased from AD 1640. Yield ratio and API exhibited great discrepancy, particularly from AD 1560 to 1660, which was the coldest period of the Little Ice Age. During this period, cold climate dampened the yield ratio but API remained at the same level. As illustrated by the above equations, such a discrepancy can only be explained by the enlargement of arable land areas. Similarly, temperature increased and yield ratio recovered since the end of the 17 th century. Since then, land area was no longer required to be enlarged for relieving slight climatic impacts. Hence, at the stable level of land area, the harvest amount increases with the recovery of yield ratio after AD 1700 (Figure 3).

Such an understanding on land input is only realized by the indirect deduction of 
mathematical analysis. This indirect association can only explain some long-term trends and cannot provide detailed fluctuations in the short-term period.

\subsection{Increasing Labor Input per Land Unit (Labor Input)}

In addition to the expansion of arable land areas, labor amount is another traditional input in agricultural production (Fan 1991). Possible production output is usually estimated by analyzing the labor input (Douglas 1976), particularly in past agrarian societies with low technological levels. In the pre-industrial era, agricultural production was labor intensive. Thus, the availability of farm labor throughout this time frame was significant (Symons 1979). Labor input also has special advantages. Compared with land, labor input is more elastic in supply (Floyd 1965) and is therefore considered the abundant and principal input (Cornia 1985).

The availability of labor was determined by the population size during the study period. Approximately $80 \%$ of the populations in the past were engaged in agricultural production (Pounds 1979). Hence, population size can be considered a reasonable indicator reflecting labor supply in the agricultural sector. Figure 2D shows that the European population size at the continental scale in the pre-industrial period increases by approximately 100 million, thus indicating the higher availability of farm labor. The regression results in Table 2 demonstrate that such an increase in population (farm labor) positively contributes to the total amount of agricultural production at the significance level of 0.05 .

In Section 3.1, the harvest amount was co-determined by the yield ratio and the amount of seeds sown (land area). If we assume that the amount of seeds sown (land area) is constant, then the yield ratio will determine the harvest amount. The contribution of labor input to boosting agricultural production relies on how it can 
contribute to increasing the yield ratio. Regression analysis was performed to confirm the contribution of increasing labor input to yield ratio (Table 3). The negative population coefficient implies that more labor input will lead to less yield ratio. These data results contradict our current understanding on labor input. Figure 2B reveals that the yield ratio in Europe during the pre-industrial era (AD 1500 to 1800) did not improve despite the sharp increase in population. Climatic impact is more dominant than the agricultural adaptation of human society; however, the negative regression results merit serious assessment. Therefore, this finding reveals that the contribution of labor input to agricultural production must be reconsidered.

The negative regression coefficients between yield ratio and population shown in Table 3 can be affirmed by two resolutions. First, we assume that labor input aims to boost yield ratio. As discussed in Section 3.1, land input is a feasible means of increasing harvest amount to adapt to climate change. After all fallow lands were used, marginal lands were increasingly converted to farmland to cope with climate change (Grove 1988, Galloway 1986). However, these marginal lands were originally unsuitable for agricultural production. Thus, if crop cultivation extended to areas with low agricultural productivity, the yield ratio would eventually decrease because of poor soil conditions. Labor input was implemented to boost yield ratio, but the overall effect of this undertaking was exceeded by the negative impact of introducing marginal land with poor quality because of the low technological level in pre-industrial society. Consequently, yield ratio decreased and incurred negative regression results. Second, the role of labor input is inconsistent with our current understanding. Labor input was augmented to increase arable lands but not to considerably boost yield ratio. More labor input leads to more cultivated lands. However, some marginal lands with low fertility were included, thereby decreasing 
the average yield ratio.

In summary, land input is a more effective and feasible means of adapting to climate change than labor input, particularly at a time characterized by a low technological level. The discussions in this study are consistent with several current ideas, thus stipulating that the technological level of agriculture in pre-industrial Europe only experienced slight modifications (Fussell 1966, Clark 2007, 2006). However, given the limitation of data on agricultural activities in pre-industrial Europe, other adaptive methods cannot be quantitatively assessed. In spite of this condition, the above findings on land and labor inputs are considered relevant because they were determined with current datasets and statistical analysis. This study does not refute other interpretations about agricultural adaptation within other temporal and spatial contexts.

\section{Adaptation in the past and Boserup's Theory}

We conduct a quantitative research to examine the roles of land and labor inputs in agricultural adaptation to climate change within 300 years and at the continental scale to fill the existing research gap. The research findings against the background of pre-industrial society provide a good opportunity to revisit Boserup's theory on food production, agricultural methods, and population (Boserup 1965, 1981).

Based on empirical data, the results of this study agree with Boserup's theory, which considers land expansion as the final approach of mitigating the tension of land carrying capacity. Boserup’s theory has been adopted by numerous studies on Africa (Tiffen, Mortimore, and Gichuki 1994, Kabubo-Mariara 2007) because the technological level in pre-industrial society is considered similar to that of current under-developed regions (Onimode 1988). This study quantitatively confirms that 
Boserup’s theory can also be applied to pre-industrial society at a large spatial and long-term scales. Under the technological level of a pre-industrial society, enlarging the arable land area will be the most feasible means of improving agricultural production.

Boserup's theory stipulates that agricultural methods depend on the population size, thus implying that people would uncover various means of boosting food production by increasing the workforce, machinery, or fertilizers. However, the results show that the yield ratio, which is a key indicator of past productivity, did not increase during the study period. Although the population size increased at least twice (approximately 100 million), as shown in Figure 2D, the society only had negligible technological improvement in agriculture according to the level of yield ratio. Hence, the current analysis can improve Boserup’s theory from the perspective of a geographic study at a large spatial and long-term scale.

Boserup's theory does not mention at which spatial or temporal scale innovation occurs under population pressure. Scale is the methodological issue inherent to observation and is the objective characteristic of complex interactions within and among social and natural processes (Sayre 2005). Every scale induces new problems that coincide with a new nature/society interface (Dolidon 2007). At a continental scale, the yield ratio in Europe did not increase during the 300-year long-term scale. In fact, humans preferred to follow their ways of life, that is, by expanding land areas than implementing changes. Nevertheless, in current societies, the majority of the adaptation methods are still based on past experience when dealing with climate-related risks (Adger et al. 2003). Technological innovation at a large spatial scale requires a long-term process. However, this study does not deny that the changes of agricultural technologies might more easily occur at a limited spatial-temporal 
scale.

Population pressure should not be the only impetus for initiating changes in agricultural methods, particularly at large spatial and long-term scales. Land input was implemented because of the cooling climate, which decreases agricultural harvest. Thus, climate change must also be considered, specifically at a large scale. Moreover, the carrying capacity of land should be interpreted with both natural constraints and human responses (Cohen 1995). Given the low food supply attributed to climate change, population pressure increases and people must seek appropriate means of maintaining their nutrition level. Many local socio-economic factors receive more attention at a limited scale of study, but these local factors with many varieties may be neutralized at a large scale. The influences of climate change are more apparent at a large scale than at a small one because the complex nature-society interactions should be disentangled at a large spatial and long-term scale (MacDonald and Iain 1998, Miller 1990, Butlin 1993).

On the basis of the above discussion, although the human society has not withdrawn their efforts to adapt to natural change, the buffering mechanism for relieving climate change during the pre-industrial era was limited (DeVries 1980, Ingram, Farmer, and Wigley 1981). Despite the instances of improved farming, the majority of the farmers have been continuously applying the traditional practices of their ancestors (Coleman 1959, Fussell 1966) as a general condition of the pre-industrial world economies (Clark 2007). Moreover, poor transportation also hinders international or interregional collaboration (Vries 1976, Pounds 1979). Despite the existence of world-system theories claiming global connection since AD 1500 (Wallerstein 1974, 1980), trade has mainly been focused on commercial agricultural products for profit (Ogborn 2000). In this regard, trade and transport can 
hardly relieve the conflicts between food supply and human demand, particularly at long term and large spatial scales (Persson 1996). New crops were then introduced to Europe to satisfy the need and demand for food, but before the second half of the $18^{\text {th }}$ century, potato was a rare crop and farmers were initially prejudiced against maize as food (van Bath 1963a). Therefore, the adaptation to climate change has experienced a long and slow process of development.

The above discussions on the limited capacity of adaptation were only based on the qualitative study and literature survey, whose scale was set as pre-industrial Europe or whole world economy. Accordingly, the importance of the above-mentioned adaptation methods such as technological improvement, food trade, or introduction of crop in agriculture at the regional or local level within a short temporal duration cannot be denied. Future case studies must be significantly focused more on small-scale studies on adaptation, providing quantitative evidence.

\section{Conclusion}

This study evaluated the effectiveness of two adaptive choices of agricultural production to climate change in pre-industrial society, namely, enlarging arable land areas and increasing labor input per land unit. Empirical data and statistical methods showed that enlarging the arable land area is a more effective means of mitigating the agricultural impact of climate change than increasing labor input per land unit at the continental and long-term scale. This result is consistent with the findings of Boserup’s theory on increasing agricultural production by enlarging arable land area in developing regions. Moreover, the findings of the empirical analysis also improved Boserup's theory from the perspective of a large geographic and long-term scale. At large spatial and long-term scales, both population pressure and climatic impact may 
encourage people to seek various means of increasing food production.

This study does not refute other theories about adaptation in agrarian society at other spatial and temporal scales. Based on the current available data, this study simply aimed to provide new pieces of statistical evidence on agricultural adaptation under climatic impact in pre-industrial society. Further studies must be performed if more fine-grained socio-economic datasets become available.

Furthermore, the conditions in China could be mirrored by the case of pre-industrial Europe as well. The major role of population as the consumer in historical China has been accepted by different scholars (Huang 1990, Elvin 1973, Lee et al. 1997). In this regard, population increase dampened the buffering capacity of the economy in late imperial China. Eventually, the economic scarcity was driven by both climatic impacts and population growth (Lee 2014). On the other hand, the population in pre-industrial Europe primarily functioned as producer indicated by our statistical results in the present study. It is in contrast with the case in historical China. This may explain why farmland was thus considered as the most important asset in historical agrarian China (Benjamin and Brandt 1997), but not in pre-industrial Europe with more productive labor. The findings in pre-industrial Europe might be useful to understand some Chinese traditions and cultures.

At last, it is observed that numerous countries remain at the low development level in the pre-industrial era. One notable implication of this study is that the government of those regions, which do not have enough fallow lands, must place more emphasis on exploring other possible adaptive methods for coping with the vulnerability of their agricultural sector to climate change. 


\section{Reference}

Adger, W. Neil. 2003. "Social Capital, Collective Action, and Adaptation to Climate Change." Economic Geography 79 (4):387-404.

Adger, W. Neil, Saleemul Huq, Katrina Brown, Declan Conway, and Mike Hulme. 2003. "Adaptation to climate change in the developing world." Progress in Development Studies 3 (3):179-195.

Benjamin, Dwayne, and Loren Brandt. 1997. "Land, Factor Markets, and Inequality in Rural China: Historical Evidence." Explorations in Economic History 34 (4):460-494.

Boserup, Ester. 1965. The conditions of agricultural growth : the economics of agrarian change under population pressure. London: Allen \& Unwin.

Boserup, Ester. 1981. Population and technological change: a study of long-term trends. Chicago: University of Chicago Press.

Brandon, P. F. 1972. "Cereal yields on Sussex estate of Battle Abbey during the later middle ages." Economic History Review 24:404-412.

Butlin, Robin A. 1993. Historical geography : through the gates of space and time. London: Edward Arnold.

Campbell, Bruce M.S. 2000. English seigniorial agriculture, 1250-1450. Cambridge: Cambridge University Press.

Chilosi, David, Tommy E. Murphy, Roman Studer, and A. Coşkun Tunçer. 2013. "Europe's many integrations: Geography and grain markets, 1620-1913." Explorations in Economic History 50 (1):46-68.

Clark, Gregory. 2006. "The Long March of History: Farm Wages, Population and Economic Growth, England 1209-1869." Economic History Review.

Clark, Gregory. 2007. A Farewell to Alms: an brief economic history of the world. New Jersey, USA: Princeton University Press.

Cohen, Joel E. 1995. "Population growth and earth's human carrying capacity." Science 269 (5222):341-346.

Coleman, D. C. 1959. "Technology and Economic History, 1500-1750." The Economic History Review 11 (3):506-514.

Cornia, Giovanni Andrea. 1985. "Farm size, land yields and the agricultural production function: An analysis for fifteen developing countries." World Development 13 (4):513-534.

D'Arrigo, Rosanne, Rob Wilson, and Gordon Jacoby. 2006. "On the long-term context for late twentieth century warming." Journal of Geophysical Research 111:D03103.

DeVries, J. 1980. "Measuring the impact of climate on history - The search for 
appropriate methodologies." Journal of Interdiscipinary History 10 (4):599-630.

Dolidon, Hélène. 2007. "La multiplicité des échelles dans l'analyse d’un phénomène d'interface nature/société.L'exemple des feux de brousse en Afrique de l'ouest." In Cybergeo, Environment, Nature, Landscape, Article 363. http://cybergeo.revues.org/index4805.html.

Douglas, Paul H. 1976. "The Cobb-Douglas Production Function Once Again: Its History, Its Testing, and Some New Empirical Values." Journal of Political Economy 84 (5):903-916.

Elvin, Mark. 1973. The pattern of the Chinese past. London: Eyre Methuen.

Ewert, Ulf Christian, Mathias Roehl, and Adelinde M. Uhrmache. 2007. "Hunger and Market Dynamics in Pre-Modern Communities: Insights into the Effects of Market Intervention from a Multi-Agent Model." Historical Social Research 32 (4):122-50.

Fan, Shenggen. 1991. "Effects of Technological Change and Institutional Reform on Production Growth in Chinese Agriculture." American Journal of Agricultural Economics 73 (2):266-275.

Fei, Jie, and Jie Zhou. 2015. "The drought and locust plague of 942-944 AD in the Yellow River Basin, China." Quaternary International. doi: doi:10.1016/j.quaint.2014.11.053.

Fischer, David Hackett. 1996. The Great Wave: Price Revolutions and the Rhythm of History. New York: Oxford University Press.

Floyd, John E. 1965. "The Effects of Farm Price Supports on the Returns to Land and Labor in Agriculture." Journal of Political Economy 73 (2):148-158.

Foley, Jonathan A., Ruth DeFries, Gregory P. Asner, Carol Barford, Gordon Bonan, Stephen R. Carpenter, F. Stuart Chapin, Michael T. Coe, Gretchen C. Daily, Holly K. Gibbs, Joseph H. Helkowski, Tracey Holloway, Erica A. Howard, Christopher J. Kucharik, Chad Monfreda, Jonathan A. Patz, I. Colin Prentice, Navin Ramankutty, and Peter K. Snyder. 2005. "Global Consequences of Land Use." Science 309 (5734):570-574.

Ford, James D., Barry Smit, and Johanna Wandel. 2006. "Vulnerability to climate change in the Arctic: A case study from Arctic Bay, Canada." Global Environmental Change 16 (2):145-160.

Fussell, G. E. 1966. Farming Technique from Prehistoric to Modern Times. Edinburgh and London, UK: Pergamon Press.

Galloway, Patrick R. 1986. "Long-term fluctuations in climate and population in the preindustrial era." Population and Development Review 12 (1):1-24.

Grove, J. M. 1988. The Little Ice Age. New York, USA: Multhuen. 
Hartmann, Hudson T., Anton M. Kofranek, Vincent E. Rubatzky, and William J. Flocker. 1981. Plant Science: Growth, Development, and Utilization of Cultivated Plants. 2nd ed. New Jersey, USA: Englewood Cliffs.

Huang, Philip C.C. 1990. The peasant family and rural development in the Yangzi Delta, 1350-1988. Stanford, Calif.: Stanford University Press,.

Hughes, Harold D., and Darrel S. Metcalfe. 1972. Crop Production. New York, USA: The Macmilan Company.

Ingram, M.J., G. Farmer, and T.M.L. Wigley. 1981. "Past climates and their impact on man: A review." In Climate and History, edited by T.M.L. Wigley, M.J. Ingram and G. Farmer, 3-50. Cambridge: Cambridge University Press.

IPCC. 2007. Climate Change 2007: Impacts, Adaptation and Vulnerability. Contribution of Working Group II to the Fourth Assessment Report of the Intergovernmental Panel on Climate Change. edited by O.F. Canziani M.L. Parry, J.P. Palutikof, P.J. van der Linden and C.E. Hanson. Cambridge, UK.

Jones, P.D., and R.S. Bradley. 1992. "Climatic variations in the longest instrumental records." In Climate since A.D. 1500, edited by Raymond S. Bradley and Philip D. Jones. London: Routledge.

Kabubo-Mariara, Jane. 2007. "Land conservation and tenure security in Kenya: Boserup's hypothesis revisited." Ecological Economics 64 (1):25-35.

Karl, Gunnar Persson. 1999. Grain Markets in Europe, 1500-1900: Integration and Deregulation. Cambridge, UK: Cambridge University Press.

Kirshen, Paul, Matthias Ruth, and William Anderson. 2008. "Interdependencies of urban climate change impacts and adaptation strategies: a case study of Metropolitan Boston USA." Climatic Change 86 (1-2):105-122.

Lee, Harry F. 2014. "Climate-induced agricultural shrinkage and overpopulation in late imperial China." Climate Research 59 (3):229-242.

Lee, James Z., Cameron D. Campbell, Chris J. Myers, and Yizhuang Ding. 1997. Fate and fortune in rural China : social organization and population behavior in Liaoning, 1774-1873. Cambridge ; New York: Cambridge University Press.

Little, Daniel. 2008. "Eurasian Historical Comparisons: Conceptual Issues in Comparative Historical Inquiry." Social Science History 32 (2):235-261.

Luterbacher, Jürg, Daniel Dietrich, Elena Xoplaki, Martin Grosjean, and Heinz Wanner. 2004. "European seasonal and annual temperature variability, trends, and extremes since 1500." Science 303 (5663):1499 - 1503.

MacDonald, and Kenneth Iain. 1998. "Push and shove: Spatial history and the construction of a portering economy in Northern Pakistan." Comparative studies in society and history 40 (2):287-317.

Mann, M.E., and P.D. Jones. 2003. "Global surface temperatures over the past two 
millennia." Geophysical Research Letters 30 (15):Article. No. 1820.

Mathias, R. J. 1990. "Factors Affecting the Establishment of Callus Cultures in Wheat." In Wheat, edited by Y. P. S. Bajaj, 35. Heidelberg, Germany: Springer.

McConnell, Campell R., and Stanley L. Bruce. 2002. Economics: Principles, Problems and Policies. 15th ed. Boston: McGraw-Hill/Irwin.

McEvedy, Colin, and Richard Jones. 1978. Atlas of World Population History. London, UK: Allen Lane.

Miller, David W. 1990. "Spatial analysis and social history." Journal of Social History 24 (1):213-220.

Moore-Colyer, Richard J. 1995. "Oats and oat production in history and prehistory." In The Oat Crop: Production and Utilization, edited by Robert W. Welch, 1, 21-29. London, UK: Chapman \& Hall.

Ogborn, Miles. 2000. "Historical geographies of globalisation, c. 1500-1800." In Modern historical geographies, edited by Brian Graham and Catherine Nash. Harlow, Essex: Longman.

Onimode, Bade. 1988. A Political economy of the African crisis. London; Atlantic Highlands, N.J.: Zed Books with the Institute for African Alternatives.

Orlove, Ben. 2005. "Human adaptation to climate change: A review of three historical cases and some general perspectives." Environmental Science \& Policy 8 (6):589-600.

Osborn, T., and K. R. Briffa. 2006. "The spatial extent of 20th-century warmth in the context of the past 1200 years." Science 311 (5762):841-844.

Özmucur, Süleyman, and Sevket Pamuk. 2007. "Did European commodity prices converge during 1500-1800." In The new comparative economic history: essays in honor of Jeffrey G.Williamson, edited by Timothy J. Hatton, Kevin H. O'Rourke and Alan M. Taylor, 59-86. Cambridge, Mass.: MIT Press.

Parker, Geoffrey, and Lesley M Smith. 1997. "Introduction." In The General Crisis of the Seventeenth Century, edited by Geoffrey Parker and Lesley M Smith, 1-31. London, Uk: Routledge.

Patz, Jonathan A., Diarmid Campbell-Lendrum, Tracey Holloway, and Jonathan A. Foley. 2005. "Impact of regional climate change on human health." Nature 438:310-317.

Pei, Qing, David D. Zhang, Harry F. Lee, and Guodong Li. 2014. "Climate Change and Macro-Economic Cycles in Pre-Industrial Europe." PLoS ONE 9 (2):e88155.

Pei, Qing, David D. Zhang, Guodong Li, and Harry F. Lee. 2013. "Short and long term impacts of climate variations on the agrarian economy in pre-industrial Europe." Climate Research 56:169-180. doi: 10.3354/cr01145. 
Persson, Karl Gunnar. 1996. "The seven lean years, elasticity traps, and intervention in grain markets in pre-industrial Europe." Economic History Review 49 (4):692-714.

Pollock, D.S.G. 2000. "Trend estimation and de-trending via rational square-wave filters." Journal of Econometrics 99 (2):317-334.

Pounds, N. J. G. 1979. An Historical Geography of Europe 1500-1840. New York, USA: Cambridge University Press.

Purkey, D. R., B. Joyce, S. Vicuna, M. W. Hanemann

L. L. Dale, D. Yates, and J. A. Dracup. 2008. "Robust analysis of future climate change impacts on water for agriculture and other sectors: a case study in the Sacramento Valley." Climatic Change 87 (1):109-122.

Pyke, Christopher R., and Sandy J. Andelman. 2007. "Land use and land cover tools for climate adaptation." Climatic Change 80:239-251.

Romano, Ruggiero. 1997. "Between the sixteenth and seventeenth centuries: the economic crisis of 1619-1622." In The General Crisis of the Seventeenth Century, edited by Geoffrey Parker and Lesley M Smith, 153-205. London, Uk: Routledge.

Sayre, Nathan F. 2005. "Ecological and geographical scale: parallels and potential for integration." Progress in Human Geography 29 (3):276-290.

Schmidhuber, Josef, and Francesco N. Tubiello. 2007. "Global food security under climate change." Proceedings of the National Academy of Sciences of the United States of America 104 (50):19703-19708.

Spencer, Milton H., and Jr Orley M. Amos. 1993. Contemporary economics. 8th ed. New York: Worth Publishers.

Symons, Leslie. 1979. Agricultural geography. Revised ed. Boulder, Colorado: Westview Press.

Thoen, Erik., Eric. Vanhaute, Erik. Buyst, and Leen. van Molle, eds. 1999. Comparative Rural History of the North Sea Area. Edited by B. J. P. van Bavel and E. Thoen, Land Productivity and agro-systems in the North Sea Area: Middle Ages-20th century, elements for comparison. Brepols, Belgium: Turnhout.

Tiffen, Mary, Michael Mortimore, and Francis Gichuki. 1994. More People, Less Erosion: Environmental Recovery in Kenya. Chichester: John Wiley and Sons.

Tol, Richard S.J., Samuel Fankhauser, and Joel B. Smith. 1998. "The scope for adaptation to climate change: what can we learn from the impact literature?" Global Environmental Change 8 (2):109-123.

Turchin, Peter. 2003. Historical Dynamics. Princeton, USA: Princeton University Press. 
van Bath, B.H. Slicher. 1966. "The rise of intensive husbandary in the Low Countries." In Agrarian Conditions in Modern European History edited by Charles K Warner, 24-42. New York, USA: The Macmillan Company.

van Bath, B.H.Slicher. 1963a. The Agrarian History of Western Europe A. D. 500-1850. Translated by Olive Ordish. Frome and London, Great Britain: Bulter \& Tanner Ltd.

van Bath, B.H.Slicher. 1963b. Yield Ratios, 810-1820: A.A.G. Bijdragen, No. 10.

van Bath, B.H.Slicher. 1963c. "The Yields of Different Crops(Mainly Cereal) in Relation to the Seed c. 810-1820." $\quad$ Acta Historiae Neederlandica 2:26-106.

Vries, Jande. 1976. Economy of Europe in an Age of Crisis. New York, USA: Cambridge University Press.

Wallerstein, Immanuel. 1974. The Modern World-System I: Capitalist Agriculture and the Origins of the European World-Economy in the Sixteenth Century. London: Academic Press.

Wallerstein, Immanuel. 1980. The Modern World-System II: Mercantilism and the Consolidation of the European World-Economy, 1600-1750. London: Academic Press.

Watson, Robert Tony, Marufu C. Zinyowera, and Richard H. Moss. 1998. The regional impacts of climate change: an assessment of vulnerability. Cambridge: Cambridge University Press.

Wood, James W. 1998. "A theory of preindustrial population dynamics - Demography, economy, and well-being in malthusian systems." Current Anthropology 39 (1):99-135.

Zhang, David D., Peter Brecke, Harry F. Lee, Yuan Qing He, and Jane Zhang. 2007. "Global Climate Change, War, and Population Decline in Recent Human History." Proceedings of the National Academy of Sciences of the United States of America 104 (49):19214-19219.

Zhang, David D., Harry F. Lee, Cong Wang, Baosheng Li, Jane Zhang, Qing Pei, and Jingan Chen. 2011. "Climate change and large-scale human population collapses in the pre-industrial era." Global Ecology and Biogeography 20 (4):520-531. doi: DOI: 10.1111/j.1466-8238.2010.00625.x.

Zhang, David D., Harry F. Lee, Cong Wang, Baosheng Li, Qing Pei, Jane Zhang, and Yulun An. 2011. "The causality analysis of climate change and large-scale human crisis." Proceedings of the National Academy of Sciences 108 (42):17296-17301. 
Figure 1. Map of Europe

Map data source: http://indiemapper.com/app/

Figure 2. Temperature, yield ratio, API, and population size in Europe in AD 1500-1800. Data were smoothed with a 40-year Butterworth low-pass filter. (A) European temperature; (B) Yield ratio; (C) API; (D) Population size (million); The shaded area represents the cold phase of AD 1560-1660, which contemporary historians refer to as the general crisis of the 17th century

Figure 3. Yield ratio and API in Europe in AD 1500-1800. The black and gray lines represent the yield ratio and API, respectively. Both data series were smoothed with a 40-year Butterworth low-pass filter. The shaded area represents the cold phase of AD $1560-1660$ 